\title{
КОНСЕРВАТИВНИЙ ПОГЛЯД: ПУБЛІЦИСТИКА РОДЖЕРА СКРУТОНА У ТИЖНЕВИКУ «THE SPECTATOR»
}

\author{
Андрій Мельник \\ Львівський національний університет імені Івана Франка, \\ вул. Генерала Чупринки, 49, 79044, Львів, Україна, \\ e-mail: andriy.melnyk12@gmail.com
}

Стаття присвячена публіцистиці відомого англійського філософа консервативних поглядів Роджера Скрутона на сторінках тижневика «The Spectator». Виокремлено основні теми його публікацій - актуалізація консервативних цінностей, критика лівої ідеології та її прибічників, захист релігії та проблеми освіти у контексті впровадження ідей рівності.

Ключові слова: публіцистика, консерватизм, цінності, ідеологія, Роджер Скрутон.

Відомий британський історик Ніл Фергюсон в інтерв’ю американському журналісту Дейву Рубіну із жалем констатував, що, якщо ще у 1980-х роках у таких університетах, як Оксфорд чи Кембридж, можна було зустріти науковців, які сповідували різноманітні ідеологічні переконання - консервативні, ліберальні, соціалістичні, марксистські, то сьогодні в академічній сфері панують ліві погляди, які поступово, але неухильно витісняють консервативні на маргінес. На зміну таким історикам, як Ричард Пайпс, який був фахівцем із російського комунізму ХХ сторіччя, приходять теоретики гендеру і фемінізму, тому, шкодує Фергюсон, студентам більше не розповідають про злочини Леніна і Сталіна, i, як наслідок, вони втрачають здатність побачити, наприклад, релігійні причини терористичних атак 11 вересня 2001 року, звинувачуючи у них, як це прийнято серед лівих інтелектуалів, сумнозвісну американську зовнішню політику [10].

Політичні погляди інтелектуалів, особливо академічних науковців, узагалі не були б великою проблемою, якщо б проявлялись лише у голосуванні за певну партію чи у прихильності до певних медіа, а не впливали б на проведення наукових досліджень. У жовтні 2018 року стало відомо про експеримент трьох американських дослідників - Джеймса Ліндсі, Гелен Плакроуз і Пітера Богосяна, які під вигаданими іменами надсилали до рецензованих наукових видань абсурдні та беззмістовні статті у галузі соціальних наук. Тексти були присвячені політично чутливим темам - таким, як соціальна і расова дискримінація, сексуальна орієнтація, культура маскулінності, ідеологія фемінізму. Наводячи вигадані дані, науковці, наприклад, «доводили», що злягання між собаками у парку варто розглядати у контексті культури згвалтувань.

(C) Мельник А., 2018 
В одній із статей, присвяченій темі фемінізму, вони переписали у гендерній перспективі фрагмент із «Mein Kampf» Адольфа Гітлера. Ще в одному «дослідженні» автори пропонували дресирувати чоловіків, немов собак, а в іншому - змушувати білошкірих студентів слухати лекції на підлозі як компенсацію за рабовласництво [1]. Із двадцяти написаних робіт сім було прорецензовано і прийнято до друку. Експеримент довелось достроково припинити через те, що ці публікації, які вийшли у цілком респектабельних наукових журналах, привернули увагу журналіста «Тhe Wall Street Journal». Метою експериментаторів була демонстрація того, що у сфері соціальних наук «істина вже давно мало кого хвилює. Головне - відповідність ідеологічним нормам: засудження пригнічувачів і підтримка «принижених». (...) Автори таких робіт усе частіше чинять тиск на студентів, адміністрацію та працівників інших факультетів, змушуючи їх висловлювати підтримку їхнім поглядам. При цьому ці погляди зовсім не є науковими» [1]. Один із дослідників, Джеймс Ліндсі пояснює: «Культура, що наразі склалася, диктує нам, що прийнятними можуть бути лише висновки певного роду - наприклад, білий колір шкіри або мужність обов'язково повинні бути проблемою. I боротьба з проявами соціальної несправедливості ставиться вище за об'єктивну правду» [1]. Результати цього перерваного експерименту показали, що гуманітарні і соціальні науки в західних університетах перебувають під сильним впливом лівої ідеології, адже висміяні у псевдодослідженнях догми $є$ обов'язковою частиною світоглядного арсеналу сучасних лівих. (Звісно, ми не ризикнемо стверджувати, посилаючись лише на один прецедент, що праві погляди не відіграють жодної ролі у науковій царині.)

Коли 1985 року відомий англійський філософ Роджер Скрутон опублікував книгу «Мислителі нової лівиці», у якій він гостро скритикував таких «володарів дум», як Едвард Томпсон, Антоніо Грамші, Жан-Поль Сартр, Роналд Дворкін, Мішель Фуко та ін., то це, за його ж словами, поклало початок кінця його академічної кар'єри [7]. Після нищівних рецензій у пресі та бойкоту в університетських середовищах, видавець відмовився реалізовувати книгу і повернув залишок тиражу авторові. У цей час Скрутон редагував консервативний часопис «The Salisbury Review» і викладав у Бірбекському коледжі Лондонського університету, де, як він пригадував пізніше, був чи не єдиним консерватором, окрім хіба жінки, яка готувала їжу в буфеті. Переконаним консерватором він став у травні 1968 року, коли на власні очі спостерігав за студентськими бунтами у Парижі. Очевидно, кожен консерватор потребує якоїсь непересічної події, якогось суспільного зламу, на тлі якого він формулюватиме свої переконання. Саме так, зрештою, робив один із батьків консерватизму, Едмунд Берк, який викшталтовував свої ідеї, критикуючи Велику французьку революцію.

Варто зауважити, що діяльність консервативного інтелектуала важко уявити без публіцистичного жанру, адже світогляд, який він відстоює, часто будується як захист усталеного політичного, культурного і соціального порядку від радикальних змін або їхніх загроз. Революція або намагання реалізувати якийсь утопічний проект активізує консервативне мислення, і формат журнальної чи газетної колонки, основною перевагою якого є оперативність, підходить для цієї активізації якнайкраще. Це, звичайно, не означає, що консервативні мислителі не схильні до позаситуативного теоретизування. Вони часто поєднують обгрунтування принципів із публіцистичними коментарями. Щобільше, останні можуть допомогти краще сформулювати перші. Творчість Р. Скрутона підтверджує цю тезу: він поєднував формування теорії 
із виступами у періодиці. У цій статті ми коротко розглянемо публікації філософа в одному із найвпливовіших сучасних британських консервативних видань - щотижневому журналі «The Spectator», редакторами якого було чимало впливових політиків, до прикладу, колишній мер Лондона і міністр закордонних справ Об'єднаного Королівства Борис Джонсон. Хронологічні межі нашого дослідження - від початку 2000-х років до нашого часу. Основні теоретичні праці Р. Скрутона вийшли впродовж 1980-1990-х років, тому у вказаний період автор, виступаючи на сторінках популярного видання, розглядав конкретні події крізь призму задекларованих цінностей. 2016 року Р. Скрутону було присвоєно лицарський титул «за служіння філософії, навчанню та публічній освіті». А 2014 року американський журнал «Тһе Weekly Standard» назвав його «найбільш досконалим консерватором із часів Едмунда Берка» [8].

В Україні Р. Скрутон практично невідомий як консервативний публіцист. Натомість українською мовою перекладались лише кілька уривків із його теоретичних праць, які були розміщені в антології «Консерватизм» $[3,5,6]$ та книга «Коротка історія новітньої філософії» [4]. Зважаючи на те, що в Україні, на наш погляд, набагато частіше перекладають важливі праці ліберальних і лівих теоретиків, ознайомлення із поглядами сучасного консервативного мислителя буде не зайвим.

32015 року статті Р. Скрутона публікують у «The Spectator» у авторській рубриці «Bad Philosophy» («Погана філософія»), що можна вважати іронічним натяком на скандальний статус правого, консервативного мислення у публічному і академічному дискурсах Заходу. За аналізований період було опубліковано 35 статей різного обсягу. Ми виділили чотири основні, на наш погляд, теми - актуалізація консервативних цінностей, критика лівої ідеології та її прихильників, захист релігії та проблеми освіти, свідомо оминаючи не менш важливі для традиційного консерватизму теми ставлення до популярної культури чи навколишнього середовища, які представлені у публікаціях у «The Spectator» меншою мірою, ніж обрані для аналізу. Перед викладом тематики статей Р. Скрутона вважаємо за потрібне зазначити, що викладене нижче не варто вважати апологією принципів британського теоретика, так і поглядами автора цієї статті.

\section{1. Актуалізація консервативних цінностей}

Незважаючи на те, що формат журнального допису не надає достатньо місця і не передбачає відповідного лексикону для теоретизування, Р. Скрутон левову частку своїх публікацій присвячує саме консервативним догмам і їх втіленню у політичній, культурній та соціальній царинах. У статті «Держава не може зробити вас вільними» він критикує Акт про права людини, прийнятий 1998 року і водночас саму концепцію прав людини, яку він називає надто декларативною і нечіткою. Прийняття цього документу загрожує британському звичаєвому праву (common law), яке замінюється континентальним цивільним правом (civil law), тобто презумпція «ти вільний, доки закон не забороняє» замінюється концепцією «ти вільний тільки тоді, коли закон чітко передбачає це». На думку Скрутона, права людини - це філософська ідея, яка не пройшла випробування судовою практикою, а була накинута згори як всезагальна $\mathrm{i}$ загальнообов’язкова. Це призвело до проблеми ії інтерпретації і втілення. Ідея прав людини була інструментом у політичній боротьбі у Європі XVIII сторіччя і зброєю проти монархії і деспотії у руках тих, хто монополізував претензію на представниц- 
тво інтересів людей. У ході Великої французької революції, після того, як спроби прийняти Декларацію обов'язків було розцінено як реакційну змову, і замість нової конституції запроваджено Декларацію прав людини і громадянина, неоднозначність концепції проявилась повною мірою. Після штурму Бастилії 1789 року у тюремних камерах було знайдено семеро в’язнів (двох із яких після звільнення повернули назад, бо визнали божевільними). Через чотири роки у застінках у жахливих умовах перебувало вже близько 400 тисяч осіб, яких судили революційні трибунали, відмовляючи їм у праві на адвоката і караючи їх за злочини, сформульовані тією ж нечіткою і філософською мовою, яка надихнула авторів Декларації, а тому іiї можна було тлумачити так, як вигідно обвинувачеві. «Вилучивши правосуддя із судів і оформивши його як філософську доктрину, революціонери таким чином забрали усі права від людей і передали їх тим, хто виклав доктрину - самопроголошеним філософам, які зробили себе королями», - підсумовує Скрутон свій по-беркіанськи афористичний погляд на Французьку революцію [23]. За його словами, сталінська конституція Радянського Союзу 1933 року теж містила декларації про права совєтських громадян, за що деякі недалекоглядні західні політики називали її чи не найліберальнішою у світі. Однак усі засоби з її імплементації перебували у руках держави, а то й особисто Сталіна. Консервативне ж бачення передбачає позбавлення держави можливості втручатись у цю сферу. Основним захистом прав $є$ не декларації, а процедури, які уможливлюють їхнє втілення. Крім цього, права слід розуміти як свободи. Цей погляд базується на припущенні, що право однієї особи - це обов'язок іншої, і цей обов'язок полягає у тому, щоб не перетинати встановленої правом лінії. Натомість соціалістична традиція закріпила за правом значення вимоги або претензії. Як формулює Скрутон, «моє право на щось $є$ не свободою, яку треба поважати іншим, а вимогою, яку вони повинні виконати» [23]. Трактування прав у такій перспективі означає зловживання незрозумілими та нереалістичними зобов'язаннями, що може вилитись у великі і нерозв'язні конфлікти. Свою критику Скрутон підсумовує згадкою про Європейську конвенцію про права людини, яка гарантує кожному право на належну освіту. Постає закономірне питання: як його реалізувати? Декларування цього права одночасно має бути чиїмось обов'язком, лише так його можна втілити. Ні Конвенція, ні британський Акт про права людини не дають чіткої відповіді, а лише посилюють неоднозначність, яка може бути серйозною загрозою для здійснення правосуддя.

У статті «Знай своє місце» [17] публіцист захищає іншу важливу консервативну цінність - соціальну ієрархію від егалітаризму і т. зв. «культури самооцінки», яка особливо згубно проявляється в освітній сфері, бо передбачає пристосування шкільних програм до інтересів дітей, відмову від оцінювання мовних і літературних здібностей і загалом акцентування на тому, що учні чи студенти мають думати про себе добре. Однак освіта полягає у тому, що дітей слід переконувати вивчати речі, яких вони ще не знають. Це може знизити їхню самооцінку, вони можуть почуватись погано, але це $\epsilon$ ціною, яку слід платити, щоб почуватись добре пізніше. Освіта має пропонувати знання і вміння, а не ілюзії, на кшталт тієї, що діти є хорошими такими, як вони $є$. Без ієрархії не має соціального просування. У суспільстві рівних немає ні поразки, ні успіху, є лише відчай, який породжує втрату надії. У справжніх, а не ідеологічно вигаданих суспільствах змагаються, конфліктують, товаришують, кохають, і все це сприяє радше відмінностям, аніж рівності. Це живі суспільства, 
де винагороджуються талант, уміння і важка праця, а зарозумілість і неосвіченість відкидають. Соціальна ієрархія не має бути ні аристократією, ні плутократією, а меритократією.

Основні принципи консервативного світогляду Р. Скрутон реферативно викладає у короткій програмній статті «Станьмо на захист справжнього розуміння свободи», пояснюючи, що їх актуальність зросла саме зараз (йдеться про 2014 рік) через тиск структур ЄС та через наслідки правління лейбористів, зокрема урядів Тоні Блера та Гордона Брауна. Головні засади консервативного світогляду такі: держава формується «знизу» через вільні об'єднання людей, а не накидається «зверху» через примус; держава - це не мета, а засіб, зокрема для захисту громадянського суспільства, яке є основою і першоджерелом держави; завдання держави - узгоджувати численні людські цілі, а не диктувати і контролювати їх; консерватори розглядають політику як засіб збереження суспільства, а не як засіб нав’язати чи створити його (на противагу як французьким революціонерам, так і творцям Свропейського Союзу); консерватори не визнають беззастережної першості наднаціональної влади $€ C$, протистоять невибірковій імміграції і класовій війні; консерватизм не визнає утопічного інтернаціоналізму світу без кордонів, тому виступає за обмеження міграції; серцем громадянського суспільства є сім'я; акцент на різниці між свободою, заснованою на особистій відповідальності та повазі до інших та вседозволеністю як способі експлуатації інших і досягненні особистої вигоди; консерватизм - філософія спадковості і відповідального управління; консерватори вірять у права людини, але такі права, які оплачені обов'язками і які примирюють людей, а не розділяють їх; консерватори вірять у вільний ринок, але не за будь-яку ціну, якість ринку і його здатність розв'язувати проблеми економічної співпраці залежить від моральних якостей його учасників (Адам Сміт і Девід Юм); наші права - це також наші свободи, а свобода має сенс лише між людьми, які відповідальні перед своїми ближніми за їі неправедне використання.

Ясна річ, задекларовані цінності не могли не привести автора до підтримки руху за вихід Британії із СС. Утім, Р. Скрутон не публікує у журналі окремого матеріалу, присвяченого референдуму чи окремої статті з агітацією за Leave. У виданні знаходимо лише два матеріали із прямим посиланням на Брекзит. У статті «Брекзит поверне нам наше село і усю країну загалом» публіцист критикує спільну аграрну політику СС, вигідну насамперед для великих агрохолдингів і згубну для дрібних фермерів. Вихід Британії з ЄС не лише дасть шанс допомогти їм субсидіями, щоб вони виробляли екологічну чисту продукцію, але й допоможе зберегти традиційний сільський спосіб життя, а також неповторний англійський ландшафт від надмірної індустріалізації. У матеріалі «Постправда - це повна нісенітниця» [18] Скрутон заявляє, що не варто пов'язувати голосування і вихід Британії з СС із ситуацією постправди, що робить чимало коментаторів. Політики завжди брехали, казали напівправду або наполягали на праві казати благородну неправду заради суспільного спокою. Тому в концепції постправди немає нічого нового. Це не породження нашої інтернет-епохи. Зневага до правди домінувала в академічних середовищах у 70-80-х роках минулого сторіччя, деякі науковці будували на цьому свої кар'єри. Попередниками цього явища були Ф. Ніцше із його знаменитою фразою про те, що немає фактів, а лише інтерпретації, К. Маркс, який замінив правду силою, у результаті чого марксизм вважався наукою, а все решта - ідеологією, яка є хибною свідомістю 
буржуазії, М. Фуко із його концепцією епістеми культури як системи ідей і понять, які накидає суспільству правлячий клас. Якщо вибори Трампа можна пов'язати із концепцією постправди, то Брекзит, на думку публіциста, - ні. Голосування за вихід з ЄС було пов'язане не з економічними страхами, а із загрозою британській ідентичності. СС задумувався як економічний і митний союз, але перетворився у бюрократичного монстра, який зазіхає на державний суверенітет. Британія вступала саме в такий союз, і політики, які ї̈ туди залучали, брехали, знаючи правду. Замість того, щоб поставити питання про перегляд договору, який укладали в інших історичних умовах, проблему звели до двох опцій - так чи ні, залишати чи залишатись. Це відбулось через тотальний вплив соцмереж, де один клік має вирішити усе.

На відміну від багатьох критиків СС, євроскептицизм Скрутона не приводить його у табір симпатиків президента Росії Путіна, т. зв. «путінсферштеєрів», які виправдовують його агресивну політику або пропонують не припиняти співпраці, незважаючи на анексію Криму і війну проти України. Навпаки, британський публіцист у статті «Брехня по-російськи» пропонує філософську перспективу постсовєтської пропаганди. Сучасна російська брехня базується на радянській пропаганді, а на Заході вона знаходить вдячний грунт, через домінування в інтелектуальній сфері теорій, які нехтують правдою - від античної софістики, від знаменитого парадоксу про мешканця острова Крит, який казав, що усі критяни - брехуни, до Ніцше, Маркса і постмодерністів. Ось як філософ описує цей процес: «Усі, хто зіткнувся із комуністичною машиною, були знайомі із скасуванням відмінності між істиною та владою... Метою Комуністичної партії було встановлення контролю над якомога більшою частиною цивілізованого світу. Міф про «капіталістичну загрозу»; опис розгортання радянських військ як «мирного наступу», а вторгнення до Угорщини, Чехословаччини та Афганістану як «братської допомоги»- все це частини постправдивої дипломатії. Свреїв переслідували не як євреїв, а як частину буржуазно-сіоністсько-капіталістичної змови. Католиків ув'язнювали за «підривну діяльність у співпраці з іноземною владою». Спроби НАТО встановити протиракетну оборону ставали актами агресії, які дестабілізували Свропу. I так далі. Результатом цього був своєрідний параноїдальний дискурс, у якому будь-які раціональні аргументи втрачали силу. Радянська пропагандистська машина зустрічала будь-який факт вигуком «Брехня!», немов божевільний логік, який постійно торочив «Це речення помилкове!» Але інституціоналізована параноя не зникла разом із колапсом комунізму. Ї̈̈ можна подолати, але лише за допомогою вільної преси, вільних інституцій та університетів, які захищають свободу слова - речей, які перебувають під загрозою в усьому «постправдивому» світі і яких впродовж століть не було у Росії. Коли було доведено, що літак малазійських авіаліній було збито над територією України російською ракетою, у відповідь знову пролунало: «Брехня!» Звинувачення російських атлетів у вживання допінгу, хакерські атаки на США, мобілізація військ на польському кордоні, переміщення озброєння у Калінінградську область, постійне порушення шведського повітряного простору - на усе це відповідь була аналогічна. Основний постулат російської дипломатії можна сформулювати так: «Правди не існує, а отже, все, що ви кажете - брехня» [22]. Ця розлога цитата - додатковий аргумент на користь того, що не усіх європейських правих варто автоматично зараховувати до симпатиків Путіна. 
Мельник $A$

\section{2. Критика лівої ідеології та її прихильників}

Обгрунтування певної ідеології нерідко (якщо не завжди) поєднується із критикою іншої. Р. Скрутон, як ми зазначали, став відомим широкій публіці не лише як теоретик традиційного консерватизму, але й гострий критик т. зв. «нової лівиці». Як у 1980-х, так і у 2000-х роках приводів для такої критики не бракувало. У статті «Сила негативного мислення» публіцист висуває чи не основні філософські претензії щодо лівої ідеології. Текст присвячений спадщині французького письменника i одного з чільних ідеологів європейської лівиці Жана-Поля Сартра і 100-річчю від дня його народження. Скрутон намагається оцінити французького нобеліанта комплексно, оцінюючи не лише його політичні й філософські, але й літературні здобутки. Власне кажучи, він не розділяє їх. Сартр, за словами публіциста, винайшов антигероя модерної літератури - стражденну свідомість, яка відмовляється від учинків і ховається всередині свого его, він апологізував моральну поставу екзистенціаліста, для якого власне «я» і його автентичність мають перевагу над кожним моральним кодексом, над кожною угодою, над кожним звичаєм, в якому інший має право голосу. Він захищав злочин як форму моральної чистоти. Він знову винайшов класового ворога Маркса і надихну цілу генерацію молодих людей, щоб вони жили у протистоянні з буржуазією - класом, який відмовився від свободи на користь нібито «поганої віри» у звичаї, інституції і закони. Сартр послідовно виступав за знищення т. зв. буржуазної Франції і його антибуржуазна риторика змінила мову і порядок денний післявоєнної французької філософії і надихнула Р. Барта, М. Фуко, Ж. Лакана, але також і Пол Пота, який повернувся до рідної Камбоджі, щоб втілювати ці постулати у життя. «Немає нічого безглуздого у тому, щоб в очищувальному гніві Пол Пота побачити презирство до всього звичайного і справжнього, яке висловлене чи не в кожному рядку Сартрової демонічної прози» [21]. Мефістофель Гете якось промовляв: я дух, який завжди заперечує. Це ж можна сказати і про Сартра, для якого пекло - це інші люди. «Як Сатана Мілтона, Сартр побачив перетворений власною гординею світ - гординею, яка зумовила відмову від усіх нагород - від Ордену почесного легіону до Нобелівської премії з літератури, адже вони походять від Іншого, а не від Себе», - зауважує Скрутон [21].

Публіцист коротко аналізує праці Сартра, його художні твори і констатує, що геніальний аналітик людського становища у «Бутті і часі» перетворився на проповідника негації у працях «Екзистенціалізм - це гуманізм» та «Критика діалектичного розуму», на захисника совєтських, китайських, в’єтнамських, кубинських і камбоджійських революціонерів саме 3 внутрішньої потреби заперечити «буржуазній» Франції, на того, хто закликав робити висновки про комунізм не за його діями, а за намірами. «Завдяки Сартру стало майже обов’язковим, щоб післявоєнний французький інтелектуал визначив себе в опозиції до «буржуазії» і підтримував діяльність, якою б вона не була, ненависної французької комуністичної партії. Сартр та його послідовники не лише піддавали остракізму таких дисидентів, як Альбер Камю і Реймон Арон, але й влаштовували проти них показові процеси та полювання на відьом на сторінках часопису «Les Temps modernes» і з ганьбою виганяли їх із кафе, де усе відбувалось - усе в цьому випадку означає Ніщо, саме з великої літери «Н» [21]. Натхненні Сартром інтелектуали змели, знищили все, що залишилось від французької католицької культури, підбуривши протестувальників 1968 року і передавши естафету із негації своїм деконструкційним наступникам із журналу «Tel Quel», зокрема 
Жаку Дерриді, який «їздив світом із своїм новим подарунком філософії заперечення» [21].

На думку Скрутона, французи досі не оговтались від Сартра і мабуть ніколи не оговтюється. Адже їм довелось жити з інтелектуальною спадщиною, яка постійно відкидала дві речі, які тримають країну разом: християнство та ідею Франції: «Саме ліві інтелектуали стали частиною політичної еліти, для котрої ніщо не $\epsilon$ таким очевидним, як відкидання національної ідеї. Саме завдяки цій еліті божевільний проект ЄС був невитравно вписаний у французький політичний процес, завдяки цій еліті заохочувалась і субсидувалась масова міграція у Францію непоступливих мусульманських спільнот, завдяки цій еліті соціалізм був настільки міцно вбудований у французьку державу, що тепер ніхто не може його зреформувати» [21]. Однак, ясна річ, Скрутонові йдеться не лише про французьку ситуацію, адже сартріанство успішно експортувалось, і сьогодні «негативне мислення» може визначати світогляд молодого прихильника лівої ідеології, який ніколи не читав Сартра і навіть не може окреслити свої пріоритети як компонент лівого спектру.

У невеликій колонці, присвяченій сторіччю більшовицького перевороту (Російської революції) 1917 року [11] Скрутон наводить очевидну для українців тезу пам'ятники жертвам фашизму зведені повсюдно, тоді як жертв комунізму зовсім не згадують. С одна популярна історична праця, яку широко використовують у школах - «Вік крайнощів» Еріка Гобсбаума, у якій автор величає російську революцію, метою якої було повне знищення російської і європейської буржуазії задля перемоги соціалізму. У цій книзі не згадується знищення судової системи, створення ЧК, жорстокі експропріації, які зруйнували російську економіку чи масовий голод, вчинений проти українських селян. Для історика сьогодні неприпустимо писати про знищення євреїв без огиди, але таке ж жорстоке знищення буржуазії можна описувати у термінах безумовного схвалення, дивується Скрутон. Очевидна спадщина більшовицького перевороту, яка й досі не втратила свого загрозливого потенціалу, ідеологія ресентименту. Коли ресентимент приходить до влади, це означає смерть політики. Адже мета останньої - не висловлювати ресентимент, а стримувати і заспокоювати його. Публіцист пригадує, як після пожежі у будинку Greenfell Tower 14 червня 2017 року, яка забрала життя 72 людей, деякі чільні політики закликали до «дня гніву» і реквізиції буржуазної власності. «Я знову почув у цих словах голос старого ресентименту. І запитав себе: як могло дійти до того, що цього уроку не засвоєно?» Здавалося б, літератури на цю тему не бракує. Серед книжок про злочини комунізму не можна не згадати справжніх шедеврів, які, радить Скрутон, має прочитати кожна добре освічена людина, - йдеться про «Північ ополудні» Артура Кестлера, «Доктора Живаго» Бориса Пастернака, «Архіпелаг ГУЛАГ» Олександра Солженіцина. Але ресентимент легко відкидає докази. Так само, як антисемітизм пережив постійні нагадування про Голокост, так само й марксистське бачення пережило накопичені свідчення його убивчої спадщини. Як свідчення цього, додамо від себе, можна навести існування у Нью-Йорку, на Мангеттені, бару «КІБ», стилізованому під радянську епоху, у якому збираються на літературні читання інтелектуали, яким, очевидно, небайдужа ліва ідеологія, але які, можливо, мають проблеми з поінформованістю або ж моральною перспективою.

Саме через такі причини Скрутон пропонує засновувати музеї, присвячені марксистській спадщині. За взірець він пропонує Будинок терору, який з 2002 року існує 
в Будапешті і у якому вшановують жертв як нацизму, так і комунізму. Для багатьох лівих інтелектуалів така модель пам'яті досі є скандальною, адже вони вважають, що обидва тоталітарні режими не можна порівнювати, бо, мовляв, у комунізму були хороші наміри, а у нацизму - злі. Наївність, цинізм і моральна релятивність такого погляду очевидні: у підсумку все зводиться до того, що мета виправдовує засоби.

На сторінках «The Spectator» Р. Скрутон критикує не лише соціалістичну традицію і їі чільних представників, але й сучасних британських політиків лівого спрямування, зокрема нинішнього лідера Лейбористської партії Джеремі Корбина [14]. Основні претензії публіциста до лідера лейбористів - це загалом основні претензії до лівої ідеології - впровадження рівності, переслідування багатих і успішних, збільшення оподаткування і загалом впровадження марксистських постулатів, які не витримують елементарної критики. Одна із головних вад лейбористів полягає у тому, що вони не пропонують позитивного бачення майбутнього, а лише базовані на негативному мисленні заходи.

\section{3. Захист релігії}

Для деяких сучасних консерваторів релігія і віра у Бога не є обов'язковими елементами їхньої доктрини. Наприклад, Дуглас Мюррей, публіцист, відповідальний редактор «The Spectator» та ідеолог неоконсерватизму називає себе атеїстом, хоча й визнає важливість християнської культурної спадщини для європейської ідентичності. Для Р. Скрутона і його традиційного консерватизму беркіанського типу релігія є надто важливою, аби проігнорувати нападки на неї. У статті «Докінз помиляється щодо Бога» [13] автор полемізує із відомим еволюційним біологом Ричардом Докінзом $з$ приводу його телесеріалу «Корінь усього зла», в якому таким коренем, звісно, називається релігія. Скрутон сперечається як із цим, так і з відомою Докінзовою теорією мемів. «Що сталося із державами, які вакцинувались від релігії-Третім Райхом і Радянським Союзом?» - запитує він. Звинувачувати релігію у війнах, які розпочались в її ім’я - це те ж саме, що звинувачувати кохання за Троянську війну. «Усуньте релігію, як це зробили нацисти і комуністи, і ви не зробите нічого, щоб зупинити захоплення Lebensraum. Ви просто усунете головне джерело милосердя в ординарному людському серці» [13]. Не варто судити усі людські інституції за їхньою поведінкою у час конфлікту, адже справжній тест для людських інституцій - це мирний час. У іншому матеріалі Скрутон знову сперечається із Докінзом та іншими «новими атеїстами» (хоч і не називає нікого з них) про те, що релігію не можна замінити наукою. «Сподівання нових атеїстів на світ без релігії таке ж марне, як сподівання, що можливий соціум без агресії або світ без смерті. Казати, що світ - це лише природній порядок речей, як це роблять фізики, так само абсурдно, як стверджувати, що «Мона Ліза» - це лише пляма з пігментів» [16]. Комунізм, який намагався витіснити релігію науковим світоглядом, зазнав поразки. I саме сакральні речі - сім’я, релігія, знання неспотвореної національної історії - допомагали вижити під час комуністичного експерименту. У статті «Молитви у камені» Скрутон говорить уже не про релігію загалом, а з'ясовує значення Англіканської Церкви для англійської ідентичності. Зокрема, він пише про архітектуру англійських сільських церков, які є не просто будівлями, не просто символами, а частиною національної ідентичності. «Вони визначають наш духовний стан навіть посеред скептицизму та зневіри. Вони стоять посеред ландшафту як нагадування про те, ким ми є і ким ми маємо бути» [19]. 


\section{4. Проблеми освіти}

На думку багатьох сучасних консерваторів, згубний вплив лівої ідеології чи не найбільше проявляється саме в освітній сфері (йдеться, ясна річ, здебільшого про країни Західної Європи та США). Як ми вже згадували, домінування професорів із лівими поглядами позначилось на університетській кар'єрі Р. Скрутона. Тому чи не кожний правий чи консервативний публіцист, який констатує домінування лівиці в сучасних університетах, змушений звертатись до освітньої проблематики, адже це очевидна територія, на які йому доведеться зіткнутись із своїми ідеологічними опонентами.

«Якщо ви спробуєте нині в авдиторії висловити переконаність у чомусь, на вас дивитимуться косо і підозріло не тому, що ви помиляєтесь, а тому бути впевненим у чомусь - дивно, і ще більше дивацтво - поділитися своєю упевненістю з іншими», констатує Скрутон у статті «Університети воюють із правдою» [24]. Сьогодні вже не можна мати переконання, вірування, принципи (beliefs), а лише думки (opinions). Така ситуація зумовлена, на думку публіциста, новою ідеологією «недискримінації» (non-discrimination), відповідно до якої сучасна освіта має бути інклюзивною, а це означає, що не варто говорити безсумнівно про будь-що, адже це може призвести до того, що люди, які не поділяють ваших переконань, почуватимуться некомфортно. Прихильники цієї ідеології вишукують і оголошують дискримінаційними ті системи переконань, які в минулому видавались об'єктивними і важливими, начіпляючи на них ярлик «-ізму» чи «фобії», а ті, хто досі їх дотримується, виглядають ідеологічними фанатиками. Якщо ви вважаєте, що люди відрізняються від тварин, то це спецієцизм. Якщо ви вважаєте, що існують реальні і об'єктивні відмінності між чоловіками і жінками, то це трансфобія. Якщо ви вважаєте, що погляди, які ведуть до масових убивств - підозрілі, то це ісламофобія. Феміністичний рух спричинив появу поняття «гендер», який впровадили, щоб замінити застаріле поняття «стать». Стать вибрати не можна, а гендер - опція для вибору. Одній із найвідоміших феміністок XX ст. Жермен Ірір, яка 2015 року мала виступити в університеті Кардіфа, заборонили говорити про об'єктивну різницю між статями, бо це могло травмувати вразливих студентів, які ще не визначились із своїм гендером. «Ми живемо у світі, в якому краще мовчати, якщо ви вірите, що є реальні і об'єктивні відмінності між людьми, і особливо, якщо це правда» [24].

У статті із промовистим підзаголовком «Безглузда ідеологія роз'їдає душу нашої освітньої системи» Скрутон виступає як проти ідеологізації освіти, так і проти спрощення і вихолощення навчальних програм. «Мета освіти - передача знань, а не соціальна інженерія» [15]. У 70-х роках минулого сторіччя навчальні заклади радикально політизували. Чимало вчителів та викладачів бачили себе продовжувачами справи активістів 1968 року, бажаючи залучити до соціалістичної справи своїх учнів і студентів. Зважаючи на це, було переглянуто шкільні програми, щоб вилучити 3 них академічні дисципліни, замінивши їх на «доречні» (ті, які відповідають часові). Менше класичної літератури, менше класичних мов (греки, латини). Всіма способами вилучались важкі предмети з навчального плану, а іспити значно спростили. Метою було передусім встановлення рівності та соціальної справедливості та маргіналізація знань як загроза реальній освіті. Слід пам'ятати, однак, що освіта корисна лише тоді, коли є самоціллю - стати освіченим. Освіта полягає у тому, щоб вимірювати свої інтереси вищим стандартом, аніж ви зараз маєте. 
Мельник $A$

Останнім часом панує егалітаристський погляд, що освіта існує заради дитини. Але, як зауважує Скрутон у статті «У чому суть освіти?» [25], держава має опікуватися освітою заради самого знання, яке є благом для всіх, навіть для тих, хто через відсутність бажання, здібностей не може його осягнути. Освітня політика, яка передбачає, що жодна дитина не має почувати себе нижчою за інших, - помилкова. В освітній сфері держава має обов'язок зберігати ті знання, які нам потрібні, які можна передавати лише за допомогою дітей, які можуть їі осягнути. Саме тому держава має бути зацікавлена у відборі, у селекції тих, хто може зберігати і передавати знання, хоча критики кажуть, що відбір поділяє дітей на успішних і невдах, і що невдахи отримують тавро на все життя. Але освіта існує не для того, щоб підвищувати самооцінку учнів. Цю ж тему публіцист продовжує у матеріалі «Для чого нам потрібні граматичні школи» Їхнє основне завдання полягає у тому, щоб готувати тих, хто зможе зберігати і підтримувати високу, елітарну культуру. Це знову ж таки суперечить ідеології лівих, для котрих такий погляд є дискримінаційним. Слід відкинути думку, що висока культура корисна лише для інтелектуальної еліти. Це так само помилково, як те, що наука чи вища математика марна для тих, хто іiї не розуміє. Університети існують для відбору тих, хто може осягнути складні науки, і тих, хто не може. Ті, хто може, опиняються у меншості. Процес навчання культури буде суттєво ускладнений, якщо через диктат егалітаризму студенти вивчатимуть пліч-о-пліч Моцарта i Леді Гагу. Наприкінці статті Скрутон, посилаючись і на власний багаторічний досвід, пропонує щось на кшталт педагогічного кредо, не позбавленого, утім, певної поетичності: «Ви не поширюєте культуру, лише навчаючи їі. Ви передаєте її за допомогою ініціації, подаючи приклад, запрошення, можливість приєднатися до іiї осягнення. Ми, вчителі, маємо показати молодим людям не тільки те, чим ми захоплюємося і чому ми захоплюємося саме цим; ми повинні продемонструвати наше захоплення. Ми маємо зробити очевидним те, що мистецтво та література, перед якими ми схиляємось, змінюють і наше життя, і ми повинні запросити наших студентів приєднатися до досвіду, який колись отримали і ми. Цим ми демонструємо повагу до усіх наших студентів. Це, безумовно, те, чого демократичний етос справді вимагає від нас» [26].

2018 року побачила світ остання на цей час книга Роджера Скрутона «Консерватизм: запрошення до великої традиції» [12], у якій автор намагається актуалізувати консервативні принципи в епоху популізму, постправди і політичної коректності. Як і у 1968 році, автор бачить у наш час виклики, які загрожують основним консервативним цінностям. Один із рецензентів книги Скрутона, автор американського часопису «The Nation», назвав іiї «застарілою і безнадійно обмеженою» [9]. Справді, консервативне мислення виглядає не надто привабливим з позиції тих, хто звик бачити в політичних ідеологіях передбачення земного раю. Як висловився свого часу Семюел Гантінгтон, «жоден політичний філософ ніколи не описував консервативну утопію» [2; 126]. Недовіра до змін, відмова від яскравих ідеалів, зацикленість на status quo усі це можна закинути консерватизмові і навіть у багатьох історичних контекстах визнати ці закиди справедливими, особливо там, де без цих змін (скасування рабства, права жінок) не було б очевидного поступу. Утім, важко заперечити користь консервативного мислення як антидоту проти бездумної соціальної інженерії, яка нехтує людською природою, або прогресивістських фантазій, авторам яких не завадило б пам'ятати про історичні уроки чи хоча б про елементарний здоровий глузд. 


\section{REFERENCES}

1. Воронін М. Науковий скандал року: вчені писали фейкові дослідження, аби викрити псевдонауку / Микола Воронін // ВВС Україна. - 2018. - 5 жовт. - Доступно 3: https://www.bbc.com/ukrainian/features-45754024

2. Гантінгтон С. Консерватизм як ідеологія / Семюел Ф. Гантінгтон // Консерватизм: Антологія. 2-ге вид. / Упоряд. О. Проценко, В. Лісовий. - К.: ВД «Простір», «Смолоскип», 2008. - С. 122-142.

3. Скратон Р. Авторитет, відданість, традиція / Роджер Скратон // Консерватизм: Антологія. 2-ге вид. / Упоряд. О. Проценко, В. Лісовий. - К.: ВД «Простір», «Смолоскип», 2008. - С. 621-641.

4. Скратон Р. Коротка історія новітньої філософії: від Декарта до Вітгенштайна / Роджер Скратон. - К.: Основи, 1998. - 333 с.

5. Скратон Р. Консервативне сумління / Роджер Скратон // Консерватизм: Антологія. 2-ге вид. / Упоряд. О. Проценко, В. Лісовий. - К.: ВД «Простір», «Смолоскип», 2008. - C. 431-433.

6. Скратон Р. Лібералізм versus консерватизм / Роджер Скратон // Консерватизм: Антологія. 2-ге вид. / Упоряд. О. Проценко, В. Лісовий. - К.: ВД «Простір», «Смолоскип», 2008. - С. 394-407.

7. Adams T. Roger Scruton: 'Funnily enough, my father looked very like Jeremy Corbyn' / Tim Adams // The Guardian. - 2015. - 4 Oct. - Available from: https://www.theguardian. com/culture/2015/oct/04/roger-scruton-my-father-looked-like-jeremy-corbyn-foolsfrauds-firebrands-interview

8. Augustine P., Reinsch R. A Populist Uprising / Peter Augustine and Richard Reinsch // The Weekly Standart. - 2014. - 16 June - Available from: https://www.weeklystandard. com/peter-augustine-lawler-and-richard-reinsch/a-populist-uprising

9. Hogan J. Roger Scruton's Conservative Moment / Joseph Hogan // The Nation. - 2018. 2 July - Available from: https://www.thenation.com/article/roger-scrutons-conservativemoment/

10. Niall Ferguson: Intellectual Dark Web, Brexit, and Trump (Full Interview) // YouTube TheRubinReport.-Availablefrom:https://www.youtube.com/watch?v=VKkNIOkGtnQ

11. Scruton R. As the left surges back, Marxism's bloody legacy is covered up / Roger Scruton // The Spectator. - 2017. - 26 Sep. - Available from: https://life.spectator. co.uk/2017/09/as-the-left-surges-back-marxisms-bloody-legacy-is-covered-up/

12. Scruton R. Conservatism: An Invitation to the Great Tradition / Roger Scruton. - All Points Books, 2018. - $176 \mathrm{p}$.

13. Scruton R. Dawkins is wrong about God / Roger Scruton // The Spectator. - 2006. 14 Jan. - Available from: https://www.spectator.co.uk/2006/01/dawkins-is-wrongabout-god/

14. Scruton R. For Corbyn, it is as if the Berlin Wall never fell / Roger Scruton // The Spectator. - 2015. - 26 Sep. - Available from: https://life.spectator.co.uk/2015/09/thecorbynist-manifesto/

15. Scruton R. How schools fell victim to the attack of the Blob / Roger Scruton // The Spectator. - 2017. - 14 June - Available from: https://life.spectator.co.uk/2017/06/theattack-of-the-blob/ 
16. Scruton R. Humans hunger for the sacred. Why can't the new atheists understand that? / Roger Scruton // The Spectator. - 2014. - 31 May - Available from: https://www. spectator.co.uk/2014/05/humans-hunger-for-the-sacred-why-cant-the-new-atheistsunderstand-that/

17. Scruton R. Know your place / Roger Scruton // The Spectator. - 2004. - 27 Nov. Available from: https://www.spectator.co.uk/2004/11/know-your-place/

18. Scruton R. Post-truth? It's pure nonsense / Roger Scruton // The Spectator. - 2017. 10 June - Available from: https://www.spectator.co.uk/2017/06/post-truth-its-purenonsense/

19. Scruton R. Prayers in stone / Roger Scruton // The Spectator. - 2012. - 10 Nov. Available from: https:/www.spectator.co.uk/2012/11/prayers-in-stone/

20. Scruton R. Stand up for the real meaning of freedom / Roger Scruton // The Spectator. 2014. - 4 Jan. - Available from: https://www.spectator.co.uk/2014/01/the-right-way/

21. Scruton R. The power of negative thinking / Roger Scruton // The Spectator. - 2005. 25 June - Available from: https://www.spectator.co.uk/2005/06/the-power-of-negativethinking/

22. Scruton R. The Russian way of lying / Roger Scruton // The Spectator. - 2017. - 23 Mar. Available from: https://ife.spectator.co.uk/2017/03/russian-way-lying/

23. Scruton R. The state can't set you free / Roger Scruton // The Spectator. - 2004. 16 Oct. - Available from: https://www.spectator.co.uk/2004/10/the-state-cant-set-youfree/

24. Scruton R. Universities' war against truth / Roger Scruton // The Spectator. - 2016. 11 June - Available from: https://life.spectator.co.uk/2016/06/universities-war-againsttruth/

25. Scruton R. What's the point of education? / Roger Scruton // The Spectator. - 2016. 3 Nov. - Available from: https://life.spectator.co.uk/2016/11/whats-point-education/

26. Scruton R. Why we need grammar schools / Roger Scruton // The Spectator. - 2015. 5 Dec. - Available from: https://life.spectator.co.uk/2015/12/why-we-need-grammarschools/ 


\title{
THE CONSERVATIVE VIEW: ROGER SCRUTON'S OPINION JOURNALISM IN «THE SPECTATOR»
}

\author{
Andriy Melnyk \\ Ivan Franko National University of Lviv, \\ Generala Chuprynky Str. 49, 79044, Lviv, Ukraine \\ e-mail: andriy.melnyk12@gmail.com
}

The article deals with the opinion journalism of the well-known English conservative philosopher Roger Scruton on the pages of the weekly «The Spectator». The main topics of his articles are highlighted, in particular, actualization of conservative values, criticism of the left ideology and its supporters, protection of religion and educational problems in the context of the implementation of the ideas of equality.

The author observes that the publicistic and philosophical heritage of both Roger Scruton and almost all right-wing and conservative thinkers is perceived as contradictory in the academic and public discourse of Western countries. However, the main principles of conservatism, which Roger Scruton suggests in his articles, are considered as an alternative to the ideas of leftist theorists, which dominate, in particular, in the academia. Roger Scruton also reveals and criticizes the main threats that come from the left ideology, that is, resentment, rejection of tradition, «negative thinking», the introduction of equality and non-discrimination, and so on. It is also emphasized that the right views of the English philosopher do not prevent him from seeing the threats of Russian propaganda and Russian resentment.

Key words: opinion journalism, conservatism, values, ideology, Roger Scruton. 